$\begin{array}{ll} & \text { Etnográfica } \\ \text { etnográfica } & \text { Revista do Centro em Rede de Investigação em }\end{array}$

Antropologia

vol. 18 (1) | 2014

Vol. $18(1)$

\title{
Gender commodification and precarity in Portuguese call centres: the (re)production of inequality
}

Mercantilização do genéro e precariedade no sector português dos call-centers: a (re)produção da desigualdade

\section{Patrícia Alves de Matos}

\section{(2) OpenEdition}

\section{Journals}

Electronic version

URL: https://journals.openedition.org/etnografica/3319

DOI: 10.4000/etnografica.3319

ISSN: 2182-2891

\section{Publisher}

Centro em Rede de Investigação em Antropologia

Printed version

Date of publication: 1 February 2014

Number of pages: 5-32

ISSN: 0873-6561

\section{Electronic reference}

Patrícia Alves de Matos, "Gender commodification and precarity in Portuguese call centres: the (re)production of inequality", Etnográfica [Online], vol. 18 (1) | 2014, Online since 14 March 2014, connection on 09 February 2022. URL: http://journals.openedition.org/etnografica/3319 ; DOI: https:// doi.org/10.4000/etnografica.3319

\section{(c) (1) \&}

Etnográfica is licensed under a Creative Commons Attribution-NonCommercial 4.0 International License. 


\section{Gender commodification and precarity in Portuguese call centres: the (re)production of inequality}

\section{Patrícia Alves de Matos}

In this article I examine the extent to which gender is a commodity in the Portuguese call centre regime of value creation; and how gendered products of labour are embedded in both historical local gender idioms and neoliberal trends associated with recent class and employment restructurings of the European economy (precarity). Despite the existence of some formal academic studies and various activist essays in web-based journals focusing on the gendered nature of precarious work, the empirical analysis and theoretical articulation of immaterial labour regimes of value creation, precarity and gender relations remains underdeveloped. This omission in the available literature greatly contributes to an implicit acceptance of immateriality and precarity as gender-neutral realms, an assumption which, as I show in this article, may lead to faulty understandings regarding contextual specificities in the constitution of gendered neoliberal subjectivities and inequalities.

KEYWORDS: call centres, immateriality, gender, precarity, Portugal, valued/hegemonic masculinity.

Mercantilização do genéro e precariedade no sector português dos call-centers: a (re)produção da desigualdade - No contexto do regime de criação de valor no sector português dos centros de atendimento telefónico, analisa-se o género como mercadoria, tendo em conta o modo como os produtos de trabalho "genderizados" (gendered) estão imbricados em idiomas locais (históricos) de género e em transformações socioeconómicas de cunho neoliberal, associadas à recente reconfiguração das classes sociais e do emprego no contexto da economia europeia (precariedade). Apesar da circulação de alguns estudos académicos - e ensaios publicados por ativistas em revistas eletrónicas - sobre genéro e trabalho precário, é escassa a análise empírica e articulação teórica entre regimes laborais imateriais de criação de valor, precariedade e relações de género. Esta omissão na literatura científica disponível contribui para a aceitação implícita da imaterialidade e da precariedade enquanto esferas neutras no que diz respeito ao género. Pretende-se demonstrar como tal pressuposto pode conduzir a uma compreensão equívoca das especificidades contextuais da constituição de subjetividades relacionadas com o género e de desigualdades produzidas por discursos e práticas cujos fundamentos radicam na ideologia neoliberal.

PALAVRAS-CHAVE: centros de atendimento telefónico, imaterialidade, género, precariedade, Portugal, masculinidade valorizada/hegemónica.

MATOS, Patrícia Alves de (patricia.r.m.a.matos@gmail.com) - Centro em Rede de Investigação em Antropologia (CRIA), Faculdade de Ciências Sociais e Humanas da Universidade Nova de Lisboa (FCSH-UNL), Portugal. 
SINCE THE MID 1990s, WITH THE INCREASING MEDIA VISIBILITY OF outsourced call centres in India or the Philippines, this kind of workplace has been seen as representative of contemporary trends associated with the restructuring of businesses and the growing relevance of emotional labour (Hochschild 1983) in the neoliberal service economy. ${ }^{1}$ The call centre sector expansion was made possible through the dissemination of flexible patterns of accumulation among corporations (Harvey 1989) and the integration of telephone and computer technologies. Call centres operating in distinct sectors of the economy (i.e. banking, telecommunications or insurance) show similarities regarding job categories and organizational workplace practices. Female call centre operators - designated by management terminology as "customer service representatives" or "call centre agents" - usually form the bulk of the workforce. Operators have the main function of answering (inbound call centres) or making (outbound call centres) phone calls from/to firms' clients in order to provide commercial and technical support, or the sale of products and services (i.e. telemarketing). Operators carry out their main function through a material apparatus composed of headphones and a telephone connected to a computer containing a set of software applications where client's data can be retrieved, modified and stored. Workers' interactions with clients are framed by bureaucratized discursive and emotional procedures, as well as a system of control and surveillance made possible by computer-based techniques of labour quantification.

The gendered aspects of call centre labour are not unexamined in the available literature but such research remains prominently focused on: (1) the feminization of the workforce and work tasks - suggesting that the valuation of women's "soft skills" in the contemporary transnational service sector $(\mathrm{Ng}$ and Mitter 2005a) is mimicking the past valuation of women's "nimble and dextrous fingers", which contributed to the relocation of manufacturing production from developed to developing economies (Elson and Pearson 1981; Nash and Fernández-Kelly 1983); (2) gender-based job segregation and career prospects - linking the sector to a "female job ghetto", characterized by aspects similar to female-dominated forms of work in the past, such as highly repetitive work tasks, low wages and employment uncertainty (e.g. Belt 2002); and (3) women's agency, identity and mobility - with recent research suggesting that call centre work might represent a platform for upward mobility, financial independence and autonomy for women (e.g. Basi 2009). At a broader level,

I This research was funded by a doctoral grant awarded by the Portuguese Foundation for Science and Technology (FCT, SFRH/BD/27684/2006). I am grateful to Steve Nugent and João Leal, whose constructive comments and insightful advice have greatly helped me to bring this article to completion. Many thanks are also due to two anonymous reviewers from Etnográfica for their encouraging and stimulating comments, and to Sophie Richmond for editorial support. This article is dedicated to the late Jill Dias, in memory of her affectionate encouragement and support. 
with some exceptions, the literature on gender and call centre labour has tended to focus more on women than men - because women represent the majority of the workforce - with an emphasis on the empowering or constraining effects of call centre work in the livelihoods of women, especially in developing economies.

As a result of the public visibility of outsourced call centres working for an English-speaking market, the transnational quality of the sector has also been more emphasized to the detriment of its embeddedness in local economic and national traditions. Nonetheless, recent research has argued for the "limited transnationality of call centre work", suggesting that call centres maintain a remarkably "national face" arising from different legal institutions and cultural traditions (Holtgrewe et al. 2009). In fact, 86\% of call centres serve their own local and regional market (Holman, Batt and Holtgrewe 2007). Moreover, while international call centres are often portrayed as harbingers of high-tech economic modernity and as containing the promise of middle-classness - an "aura of white-collar respectability" (Bear 2007) - for its young recruits, in central and southern Europe the sector is much more connected with the "shrinking of the middle-classes" (Sassen 1998: 46) and neoliberal labour market reforms, expressed in a high incidence of casual, precarious and unprotected forms of employment, particularly among young people (Frade, Darmon and Laparra 2004), aspects that are apparent in the Portuguese context.

In the last decade, the Portuguese call centre sector has been transformed into the main symbol of precarity (precariedade laboral). The categories of precarious labour (trabalho precário) and precarity (precariedade laboral) have entered everyday language and are used by politicians, journalists and citizens protesting against the growing insecurity of formal wage employment and the rising prominence of flexible forms of employment, such as temporary agency work. The main strategy for hiring workers in the Portuguese call centre sector comprises the outsourcing of call centre activities to temporary work agencies. Workers hired in these conditions receive a low income, fewer social benefits and face poor career prospects, given the short duration of employment contracts. The politicization of the call centre sector has intensified since the late 2000 s due to international and domestic political-economic trends affecting the sector (e.g. the impact of the international financial crisis; national social tensions manifest in public demonstrations against the deregulation of labour relations and rising rates of unemployment in the country). The media, social movements against casualization, left-wing parties and trade unions increasingly started to depict call centre work as a defining feature of the young workers who comprise the "500 euros generation" (geração dos 500 euros): overqualified and stuck in low-wage employment. Against this, the sector has been hailed by the government and employers' associations as an "important source of employment" for youngsters entering the labour market. 
The categories referred above - precarious labour and precarity - are not particular to Portugal; they are widely used in Spain, France or Italy. Since 2000 they have been mobilized by social activists within countries of central and southern Europe as a critical way of addressing neoliberal shifts associated with labour market reforms, leading to widespread employment casualization, welfare cuts and changing citizenship regimes. Within this context "precarity" designates the condition of permanent insecurity and contingency in labour and social reproduction, particularly among young generations (Foti 2004). The members of anti-precarity (casualization) social movements were particularly influenced by the works of autonomist Marxists, such as Hardt and Negri $(2000,2005)$, for whom increasing employment casualization is parallel to the growing prominence of immaterial forms of labour in post-Fordist capitalist production. ${ }^{2}$ While recognizing the exploitative dimension of employment precariousness, autonomist Marxists contend that the increased centrality of communication, knowledge and affect in contemporary capitalist value creation (Lazzarato 1996) may enable the constitution of communities of cooperation and solidarity beyond the walls of the workplace, leading to "a kind of spontaneous and elementary communism" (Hardt and Negri 2000: 294) among precarious immaterial labourers. Thus there is an implicit suggestion that the condition of precarity could represent an emancipatory opportunity for the emerging collective political subject who is claimed to have replaced the proletariat of industrial societies: the precariat. Other authors have contested the theoretical and practical plausibility of the notion of the precariat, which instead is seen as fragmented along the lines of class, gender and ethnicity (Federeci 2008; Mitropoulos 2006; Ross 2008, 2009; Wacquant 2008). In his recent book, Standing (201 l) argues that the increased precariousness of employment relationships is tied to neoliberal shifts in public policies - in particular those that have increased labour market flexibility and class fragmentation. The precariat represents a global class in the making (not yet a class in or for itself) marked by a high degree of heterogeneity (e.g. highly qualified workers with irregular income sources or low-wage migrants), and lacking political agency, workplace-based security and citizenship rights.

The above authors illustrate the growing interest among academic researchers vis-a-vis the themes of precarity, precarious labour and the class status of the precariat. Despite the existence of some formal academic studies and various activist essays in web-based journals focusing on the gendered nature of precarious work, the empirical analysis and theoretical articulation of immaterial labour regimes of value creation, precarity and gender relations remains underdeveloped. This omission in the available literature greatly contributes to an 
implicit acceptance of immateriality and precarity as gender-neutral realms, an assumption which, as I show in this article, may lead to faulty understandings regarding contextual specificities in the constitution of gendered neoliberal subjectivities and inequalities.

Thus, this article focuses on the underdeveloped articulation between immaterial labour regimes of value creation, precarity and gender relations, while aiming to contribute to the growing anthropological and sociological research on the gendering of knowledge work (Freeman 2000; Mukherjee 2008; Ng and Mitter 2005b; Patel 2010; Upadhya 2006; Upadhya and Vasavi 2006). I examine the extent to which gender is a commodity in the Portuguese call centre regime of value creation, and how gendered products of labour are embedded in both historical local gender idioms and neoliberal trends associated with recent class and employment restructurings of the European economy (precarity).

The empirical data presented in this article derives from ethnographic research carried out between August 2007 and January 2009 in a call centre belonging to a private sector telecommunications company (which I will call EVA) in Lisbon, Portugal. This call centre provides technical support for the corporate segment of clients and operators are predominantly male. While on fieldwork I also had access to other helplines (i.e. commercial helplines, where operators are predominantly female), which were located on the same open-plan floor. I spent eight hours a day inside the call centre, five days a week, on morning, afternoon or evening shifts, shadowing the work tasks of operators, team leaders, the team coordinator and the area coordinator. Fieldwork involved, among other tasks, attending team meetings, training sessions, recruitment interviews; listening to calls between operators and clients (recording of calls was not allowed); as well as 40 semi-biographical interviews with operators and team leaders working at EVA, as well as in other call centres.

I develop two main arguments. First, I argue that, in the call centre regime of labour, control over the extraction of surplus value is achieved not only by Tayloristic management techniques or the introduction of new machinery/technology leading to the increasing deskilling of the workforce (Braverman 1974), but also by the mobilization of a gendered redefinition of skills valuation which implies both (female) deskilling and (male) upskilling - embedded in a pre-existing dominant gender order (Connell 1987) particular to the Portuguese context and specificities of the labour process. I show how a sexual division of labour is a device used by management to create specific kinds of customer relationships, and how, in the process of doing this, gender is embedded in commodified products of labour. ${ }^{3}$ Thus I suggest that the literature on

3 According to Marx, "commodification" refers to the process whereby the products of human labour arising from socio-historical social relations assume "the fantastic form of a relation between things" (1990 [1867]: 165) established within the act of exchange (market). The process I [continues] 
gender and call centre labour has overemphasized the valuation of women's labour and femininity in this site of affective labour, leaving relatively unexamined how gender as a social relation structurally constrained by contingent local and national traditions is put to work by management. Second, by looking at the interplay of gender, precarity and frustrated projects of social mobility towards middle-class distinction among young people in contemporary Portugal, I argue that male call centre operators deploy and enact masculinity as a form of cultural capital (Bourdieu 1986). This capital is put into play in order to enhance male call centre operators' workplace and class status vis-avis their working-class parents and female colleagues working on the commercial helplines. Therefore, following up on the argument outlined above, I argue that neither immateriality nor precarity are gender-neutral realms. Rather, as I show, immaterial regimes of value creation and individual investment strategies of self-valuation and status interact through historically constituted dominant traditions of gender relations. At a broader level, I aim to show that the Portuguese call centre sector is not only (re)producing long-lasting images of female subordination and masculine privilege mediated by enduring gendered features of the Portuguese labour market, but also reinforcing unequal gendered patterns of social mobility.

The article is structured as follows. In the next three ethnographic-based sections I examine the specific mechanisms of the call centre labour process contributing to the undervaluation of feminized skills and the valuation of masculinized skills. After, with the aim of bringing to light the contingent dominant historical gender order facilitating the undervaluation of women's labour in the contemporary Portuguese call centre sector, I offer a brief historical interlude which traces Portuguese women's rapid and massive entrance into the labour market via formal employment since the 1970s to the present, and the parallel persistence of economic and cultural features undermining gender equality and strengthening women's (and femininity) subordination. Finally, with a view of following up, and expanding, the analysis of the historical prevailing features sustaining gender inequality, I explore how the contemporary intensification of precarity combined with social mobility anxieties and particularities of the call centre labour regime enables valued masculinity to be instrumentalized as a social asset among male operators. In particular, I show how masculinity as a form of cultural capital is put into effect both within and outside the workplace.

[continued] mention of embedding gender in commodified products of labour broadly consists in selectively objectifying and assigning a commercial value to the social properties of workers' voices based on a hierarchical gendered distinction between masculine and feminine ways of talking. 
MAKING DISTINCTIONS:

COMMERCIAL AND TECHNICAL CALL CENTRES, FEMALE AND MALE VOICES

Bourdieu (2001 [1998]) argues that the "lived consensus" regarding masculine domination in the social order is first of all inscribed through the body. The biological differences between the male and female bodies are socially defined and "can thus appear as the natural justification of the socially constructed difference between the genders, and in particular of the social division of labour" (2001 [1998]: 11). The bodily encounter between masculine domination and capitalist strategies of accumulation has for a long time been the subject of ethnographic inquiry (Ong 1987). Recent studies have addressed the manufacture of gendered bodies in the dynamics of flexible specialization - illustrated by the merging of the "inflexible and untrainable female subject" and the "trainable flexible male agent" (Wright 2006) - while others have emphasized the contingency and variability through which representations of femininity and masculinity are strategically mobilized by management with the aim of putting into effect "profitable working bodies" on the shop floor (Salzinger 2003). As will become clearer to the reader throughout this section, the reality encountered in the call centre regime of labour, albeit different in specific aspects, carries with it the principle of profit maximization through the hierarchization of gendered bodies and their parts, such as voices.

The main work carried out by operators, in both commercial and technical helplines, is done with their voices. Operator and client meet each other in a telephone conversation in which the voice of the operator is supposed to encapsulate the desirable characteristics for a certain kind of service. In call centres "the customer is king", the client is the central entity in management discourse and practice, and is also the leitmotif by which work organization and work relations are defined. The need to fulfil clients' expectations vis-a-vis the service being provided shape the form through which gendered labour as service is mobilized within the call centre sector. Thus, in the following sections, I explore how management exploits both femininity and masculinity as products which are commodified in the service rendered to the client, with the aim of showing how the differential valuation of male and female voices (and the skills they are intended to express) is sustained in the call centre labour process and enacted on the shop floor in daily interactions among managers, team leaders and operators.

The technical call centre in which I conducted fieldwork illustrates the opposite scenario to the feminized mass-customer call centre. That is, out of a group of 54 workers, 52 were men. The group of men with whom I had the closest contact were aware that they were working in a "female-dominated occupation". One of the most pronounced and deliberate examples of the engendering of call centres in Portugal was achieved through advertising. 
At the beginning of the twenty-first century, the most common image of call centres in Portugal was presented daily in a television advertisement for an insurance company. In this advertisement a young girl with perfect dress, hair, gestures and words answers the telephone and says: "Hello, my name is Marta, how can I help you?" This image (among others) contributed to the idea of clean, safe and "female-friendly kind of work". ${ }^{4}$

A June 2008 report concerning outsourcing - commissioned by the firm where I conducted fieldwork - outlined the typical profile of a call centre operator: "female, single, with secondary school education, living in Lisbon and with an average age of 30 years". This feminized statistical profile only partially matched what I had seen while walking around the different call centres at EVA. While commercial helplines are mostly staffed by women, technical helplines are mostly staffed by men. In informal conversations, when I asked managers why there was a sexual division of labour between commercial and technical support, the answers were usually evasive. In response to this question the team coordinator of the technical support helpline suggested that commercial helplines were mainly "designed to deliver information", while technical helplines were more "demanding" in terms of the information being given to the client, requiring creativity from workers due to the unpredictability of the technical problems raised by clients. When I asked him if the company deliberately segmented the workers it hired, he denied it. He denied that this was the firm's responsibility and cited the social and cultural consensus, which treats men as being more suited to technical work:

"I think the social understanding which is rooted in us [Portuguese] is that technical areas are areas for men. This means that if a client calls a technical line and he is answered by a man most likely he will be more satisfied and reassured than if answered by a woman. Concerning commercial helplines it will be the reverse... I think that socially we still have that orientation..."

Thus, according to managers and coordinators, the cultural ingrained dominant gender idiom prompts the provision of hierarchical gendered products because clients tend to prominently equate a female voice with sympathy, availability and docility, and a male voice with creativity, technical capacity and determination. Nevertheless, as pointed out by Salzinger, concerning the "trope of productivity femininity" within Mexican maquiladoras, gendered subjectivities are not culturally ready-made, as the above quotation from the team coordinator may imply, they are "made on the job" (2003: 151). Similarly, 
what I found at EVA is that the feminization of work tasks was not the only strategy deployed by management to control and discipline labour according to profit-maximization motivations. At EVA there is a profitable coexistence of the undervaluation of feminized skills and the valuation of masculinized skills, mediated by contextual cultural and historical specificities (examined below), but also as a result of the specific way in which the architecture of labour extraction is organized and enacted on the shop floor.

\section{CONTROLLING AND EVALUATING THE ENACTMENT OF GENDERED SKILLS}

In this section I examine how the different deployment of disciplinary mechanisms, methods of (labour time) quantification and surveillance in commercial and technical call centres presuppose an unequal gendered valuation of skills as a means of controlling the levels of profit initially projected in the service agreement between EVA and the temping agencies. On EVA's shop floor, control over the workforce is exerted by both EVA's representatives (the area coordinator and the team coordinator, both permanent employees of the company) and the temping agency (through the team leaders, who are temporary workers). Shared control over the workforce derives from the necessity for both parties of abiding by the service agreement established between EVA and the services provider (the temping agencies), which is composed of "fixed costs" and "variable costs". The fixed costs for the client (EVA) can be established according to one of these items: (1) each hour of the operator's work; (2) each call answered; or (3) the total number of calls answered per month. The "variable costs" are dependent on the "service level agreements" (SLAs) between the two parts establishing common goals for the number of calls answered per hour and day; the average duration time of each call, etc. If the outsourcer (the temping agencies) does not achieve a standard specified in the SLAs it is their responsibility to compensate the client (EVA) in monetary form.

Commercial and technical operators apparently do the same thing with the same goal - answer phone calls and ensure the client's satisfaction. Workers providing commercial or technical support are subjected to mechanisms of labour control which take the form of qualitative and quantitative targets of work - defined by EVA. Qualitative targets consist in following a set of standardized rules of emotional display and speech which strongly determine the emotional/linguistic content displayed in the interactions between operators and clients. The rules to be followed by operators imply showing amiability and sympathy towards the client ("to have a smile in your voice"); the use of a consistent set of salutation expressions ("Hello, my name is X, how may I help you?"; "To call the client by their first and last name"); following pre-established speech acts of politeness ("Say 'thank you' before and after the hold"; 
"When you put the client on 'hold', you should regularly return to the line, the client should not wait more than 2 minutes"); and the selected use of words and expressions to manage the client's emotional state ("Make your speech positive by eliminating negative expressions", or "Present alternatives to the clients before presenting limitations"). These guidelines form part of the company's strategy of building a specific brand image which clients may be able to consistently recognize in their repeated telephonic contacts with the company (Cameron 2000: 324), but they are also means of labour extraction and surveillance. Workers' phone calls are recorded and stored in a specific database to which only coordinators and team leaders have access. The calls are routinely monitored by the team coordinator and the team leaders, by either tracing the calls in real time (i. e. "silent listening") or by randomly choosing a call from the database. The quantitative targets of work refer to a specified number of calls answered during the day and per hour, the average call duration, or the time spent by each worker on breaks and lunch time. These methods of quantification usually take the form of daily productivity reports delivered to operators by team leaders. Further, self-surveillance is instilled through a noticeboard attached to each call centre that displays real-time information regarding the number of operators logged into the system, the number of calls waiting on line or the number of workers on break.

Deborah Cameron (2000) observed that the commodification of language in call centre work involves both scripting (standardization) and styling (genderization). "Styling the worker" within call centres involves establishing frames for how to talk; and these frames are symbolically coded as feminine; "the style is gendered, produced through a consistent and deliberate preference for ways of speaking that are symbolically coded as "feminine" (Cameron 2000: 333) to show a smile in the voice, expressive intonation, rapport/empathy, minimal responses. In contrast, what I found at EVA was that although both commercial and technical operators need to abide by certain rules on what to say, how they say it is embedded in an unequal gendered valuation of skills. This is partly because the contractual conditions under which operators in commercial and technical support have to balance the qualitative and quantitative requirements of the job are not the same. As a result, these differentiated contractual conditions allow for the controlled enactment of (less valued) feminized and (more valued) masculinized ways of speaking.

Commercial helplines are mostly contacted by private/residential clients and have a high flow of calls. According to the service agreement, EVA pays the temping agency a fee calculated according to the number of calls answered per month. The emphasis is on quantity. Workers' linguistic engagement with clients is entirely scripted - words and phrasing to be used by operators are displayed on the computer when the call is initiated - which allows an increase in the speed of each call and reduces speech creativity and variation. These scripts 
also serve to fulfil the client's expectation of feminized sympathy, demeanour and docility - characteristics which shape the elaboration of scripts by the company. Informally, commercial operators are further instructed that, to protect themselves, they should not react in the face of provocations or insults from angry and abusive clients. Operator's display of reverence towards the client is "rewarded" with a structure of pay which includes incentives according to the number of calls answered. Full-time operators have a daily target of 2300 points, receiving two points for each call answered. If operators exceed the target they are paid 0.50 euro per call answered.

In contrast, with the exception of peak times, technical helplines have a lower flow of calls. EVA's monthly fixed costs towards the temping agency comprise the number of hours of work contracted. The emphasis is on quality, operators do not answer calls according to pre-answering scripts and their structure of pay includes a fixed wage with no incentives attached. The absence of answering scripts does not prevent management, particularly via team leaders, of informally instructing operators that, besides "showing a smile in their voices", they also need to "show security and determination in their voices". Further, operators are made aware that errors in technical assistance may jeopardize the client's fidelity - particularly in the corporate segment - because the services being provided by EVA are crucial for the everyday running of firms and companies. As a result, although technical operators are subjected to the same formal mechanisms of control and surveillance as commercial operators - intended to monitor their level of balancing the quantitative and qualitative targets of work - the labour of the former is mobilized by allowing the valuation of masculinized skills. Therefore, male operators are reminded of their role as "technicians", whose specific skills allow them to take an "active" role in the call, in contrast to the "passive" role of their female colleagues doing commercial support.

\section{THE SOVEREIGN CLIENT:}

\section{MYSTIFYING HIERARCHIES AMONG CLIENTS AND WORKERS}

The figure of the sovereign client as an instrument of labour control is put into effect through the process of recruitment, weekly training sessions, marketing operations and ritualistic gatherings (e.g. Christmas dinner). In all these events symbols of the central imperative of workers' "orientation towards the client" figure prominently and the company's slogan - "we need to take good care of our clients" - is materialized in the form of badges, t-shirts given to workers for free and posters stuck onto walls. By imposing on workers the abstract figure of the "sovereign client" the company seeks to obscure clients' segmentation according to their market value. That is, EVA (like other companies) differentiates between more and less important clients. For instance, the great majority 
of clients requiring commercial support are private/residential clients. ${ }^{5}$ Despite representing the great majority of EVA's clients, they are not value-added clients (i.e. clients with high billing accounts). These are clients mostly with top-up mobile phones or land-line phones, whose fidelity as clients is essential for EVA's survival as a mass-market company, but they are clients whose companies' projected expectations (i.e. caring service) and needs (i. e. activation of voice mail or roaming service) can be subjected to service massification while ensuring profits control. This is achieved by EVA through the use of answering scripts and a display of feminized skills which fulfil clients' expectations of ready availability and a caring service. In contrast, value-added clients encompass corporate and small-sized enterprises whose commercial and technical needs can only be met through a certain degree of customization. The degree of customization is controlled by EVA by deploying computer-based mechanisms of labour quantification and quality surveillance of calls as in commercial support, but only to the extent that they are not detrimental to the fulfilment of client's expectations and needs. In other words, EVA may force commercial operators to increase the speed of service for roaming activation among private clients, but knows that it would be unwise to demand the same speed for technical operators screening for difficulties in the voice services, broadband, fax, domains and web hosting of a small-sized enterprise. Thus, the lack of scripts among technical operators is put into effect to fulfil the customer's expectation of masculinized confidence and technical competence.

The hierarchical valuation of women's and men's labour is sustained, while at the same time obscured, by mobilizing workers through specific practices legitimated by the rhetoric of the "sovereign client". Among (mostly female) commercial operators the "mission of good service provision" is set in motion, in compulsory weekly training sessions and in the everyday life at the call centre, by engaging workers in the "group spirit" and the "values of working for the team" through the delivery of monthly productivity (monetary) awards for the best team. A sense of collectivity among operators is disrupted by creating the illusion of an authentic "team spirit", based on ties of friendship not limited to the workplace, which implicitly evoke stereotypes associated with feminized bonds - contributing to cooperation among team co-workers and leading to increases in the productive output of each team. Among technical operators, the smaller number of workers makes team-working relatively ineffective in ensuring adhesion to the "cult of the customer"; workers" mobilization for the provision of "good customer care" is secured by allowing the coexistence of masculine

5 Corporate clients may also require commercial support, but they do not need to contact call centres. These are clients to whom the company designates an account manager whose main responsibility is to act as intermediary between the client's requests and the company. I did not conduct fieldwork among account managers, having had only two or three informal encounters at EVA. Nevertheless, account managers are predominantly men and permanent employees of EVA. 
comradeship and some degree of individual competition among workers. ${ }^{6} \mathrm{Com}-$ petition is often encouraged by resorting to metaphors which associate masculinity with self-control, mental agility and technological mastery.

The discourses described above and the practices they sustain - the enactment of feminized friendship bonds (in commercial support) and the praise of masculinized individual competition (in technical support) - actively contribute to mobilize workers for the provision of "good customer service", while also serving the purpose of minimizing contention over the hierarchical valuation of clients and workers. Thus, commercial operators often underscored the importance of being part of a collective - the team - as a source of work motivation and structure of support to manage the most stressful tasks, such as dealing with abusive and angry clients. On the other hand, technical operators praised the beneficial effects of manly competition in bringing about emotional toughness among operators, leading some operators to develop the ability to "be in control of the call" (controlar a chamada). "Controlling the call" is a compliment directed at those operators who have developed the "special mastery" of dealing with insults and humiliations in a way which disguises their acts of subserviency and deference towards the clients.

At EVA, the "sovereign client" rhetoric masks the company's strategy of market segmentation (through which clients' needs and expectations are targeted and service labour products manufactured in a differentiated manner) and the implicit mobilization of gender as a tool of competitive advantage, enabling undervalued feminized massification (in commercial helplines) and valued masculinized customization (in technical helplines) of customer care. ${ }^{7}$ The commodification of feminine subordination and masculine authority, at the core of EVA's regime of value, is facilitated by historical and cultural specificities pertaining to the Portuguese context, while at the same time enhanced by recent neoliberal shifts in the labour market (precarity) and gendered projects of social mobility among the male "500 euros generation" currently working in call centres. To these aspects I now turn in the next two sections.

\section{PORTUGUESE WOMEN IN THE LABOUR MARKET:}

\section{BETWEEN SUBORDINATION AND EMANCIPATION}

The ideal-type of the "male breadwinner" had an inconsistent presence in recent Portuguese historical reality, for reasons broadly related with necessity (i.e. poverty) and choice (i.e. women's investment strategies in social mobility

6 Commercial helplines usually have between 100 and 150 operators covering day and night shifts; technical helplines have between 35 and 50 operators, and the night shift, from $00.00 \mathrm{am}$ to $08.00 \mathrm{pm}$, is usually looked after by just one or two operators.

7 Casaca (2012: 99-100) makes a similar point in her analysis of front-office and back-office operators belonging to the same helpline. 
through educational achievement and paid employment) (Cardoso 1996). In this section I analyse the particular social and economic conditions under which women's integration in the labour market has been achieved in the recent history of the country. Such brief analysis has the aim of specifying the historically and culturally contingent roots of the dominant gender order which is being mobilized in the valorization process of the call centre regime of labour (described in the previous sections).

In Portugal, the market's successful absorption of female labour power, particularly from the 1970s onwards, conceals latent mechanisms of discrimination, segregation and gender inequality due to the complex interconnection of several factors, including the resilience of a rhetoric of women's subordinated status as the main carer and homemaker (inherited from almost half a century of a patriarchal dictatorship), as well as structural vulnerabilities of the Portuguese state and economy. Portugal was governed for more than 40 years by a dictatorial regime (Estado Novo, 1933-1974) which, through legal and customary practices, enforced a model of patriarchal familialism - a gendered ideology of social regulation greatly shaped by the pervasive influence of the Catholic Church. The model of capitalist development enforced by the corporatist regime was sustained by a predominantly rural country, high levels of illiteracy and a tradition of labour devaluation in the fields and in the factories (Rosas 1998). From the 1960s onwards, under the auspices of the post-Second World War economic expansion, there was a progressive opening of the country towards foreign investment and growth of the industrial and service sectors. A rural exodus towards the newly industrialized coastal cities increased at the same time as available masculine labour power decreased - due to mass emigration and military mobilization for the colonial war (1961-1974). These shifts provided favourable conditions for women's increased participation in paid work, such as in factories or as domestic servants in the main urban centres. Nevertheless, in 1970 the feminine labour force participation ratio was still below 20\% (Silva 1983: 30).

The emancipatory and egalitarian values attached to the Carnation Revolution (1974) opened the way for important legal measures aimed at displacing the highly discriminatory legal framework for women. ${ }^{8}$ Over a very short period of time, women's participation in the labour market, and later in higher education, changed dramatically. Within a decade (1970s-80s) female labour market participation in Portugal changed from being among the lowest within the European context to one of the highest (Ferreira 1993: 235) - a situation which has remained unchanged until today (Eurostat 2013: 133). In the course of a generation (1990s-2000s) women's access to higher

8 Portugal was among the first countries in Europe to legislate a "law of equality" in employment and labour relations, in 1979. 
education changed as rapidly as women's entrance into paid work. Whereas the majority of women who lived through the years of the dictatorship - particularly among the working classes - only had access to primary education, their daughters and grand-daughters saw in educational achievement a route to independence and social mobility. ${ }^{9}$ Nonetheless, it should be noted that: (1) women's progressive attainment of higher education qualifications was parallel to a progressive devaluation of academic degrees, as a result of a pronounced decrease in the availability of jobs and (2) gendered inequalities in earnings and access to high-ranking job posts persisted. For example, despite the feminization of higher education, the higher the level of educational qualification, the higher the wage gap between men and women. ${ }^{10}$ Authors argue that such persistent discrimination resulted from women's attainment of civic and social rights following the Carnation Revolution, being more the result of state interventionist efforts of modernization (as expressed in investments towards the mass expansion of higher education) than of mass feminine struggle and mobilization - leading some authors to speak of "top-down" state feminism (Ferreira 1999), or "modernization without emancipation" (Torres 2009).

From the 1970s onwards, women's increasing access to jobs, careers and educational qualifications coexisted with pronounced gendered asymmetrical social practices grounded on specific cultural predispositions and customary practices - extensively reported by anthropologists (Almeida 1996; Pina-Cabral 1986) - tending to reinforce the subordination of women, as expressed in the prevalence of a traditional and conservative gendered division of household and caring tasks being reproduced up to the present (Perista 2002; Torres 2009). Moreover, since the revolutionary period the Portuguese state has demonstrated a persistent duality, which often translates into an acute discrepancy between the progressive legislation produced and the allocation of means and resources to ensure the practical effectiveness of such laws (Santos et al. 1990). Such "state duality", alongside a late-developed and deficient welfare state, contributed to the increased feminization of employment from the 1980s onwards until the present, while simultaneously neglecting the effectiveness of formal equality among men and women. The state's passive complicity with gendered asymmetrical social practices is manifest in the lack of investment in child care or welfare provision to older people (as in Nordic countries); or lack of systematic inspection of public situations of sectoral gender gap wage differentials

9 In one of the few studies concerning gender and social mobility in Portugal, Mendes (1997), drawing on a 1995 survey of a significant sample of the Portuguese population, concludes that, especially for women and in contrast to men, educational credentials were decisive in increasing the levels of intergenerational social mobility.

10 Data retrieved from the governmental website of the Commission for Equality in Labour and Employment (CITE: http://www.cite.gov.pt/pt/acite/mulheresehomens02.html, accessed 2014, February). 
among workers performing the same tasks, as well as recurrent practices of discriminatory practices towards pregnant women (Ferreira 1999: 213).

Portugal's entry into the EU in 1986 was followed by a wave of privatizations in key economic sectors, an emphasis on "free market" rhetoric and a definitive change in the economic structure characterized by the growth of the service sector (which includes call centres), and a parallel increasing devaluation (i.e. casualization/precaritization of employment relationships) and feminization of the labour force (Casaca 2010). Since the country joined the Eurozone in 1999, economic adjustment policies have prominently targeted adjustments in the price of labour, as expressed in legislation being passed in parliament with the intent of increasing the flexibility of employment and labour relations. ${ }^{11}$

Cardoso (1996: 2) argues that women's integration in the economy (via paid employment), since the early mobilization during the 1960s, accelerated by the revolutionary process and after inclusion in the EU, was strongly influenced by an economic development "strategy of competitiveness in international markets, which persistently relies on low wages". Thus, from the 1960 s onwards, within the context of increasing market liberalization and opening of the economy to foreign investment, the regime shifted from an economic strategy of import-substitution to export-based growth. The early mobilization of female labour power mentioned earlier for this period (1960s-70s) was particularly noticeable in manufacturing and agriculture, due to the slowly development of the service sector. In agriculture, women replaced men and in manufacturing women's presence rose sharply, particularly in labour-intensive industrial sectors such as textiles, footwear and wood.

During the 1980s and 1990s, agriculture and manufacturing lost their prominence in absorbing the available female labour power in favour of the service sector - particularly sectors that require skills naturalized as feminine attributes, such as personal and cleaning services, education and health. At the same time, women's share of employment in some manufacturing sectors was strengthened, particularly those relying on cheap labour power, such as clothing and footwear, where in 1991 the female labour force was over $50 \%$ - having been at the level of 6\% in 1960 (Cardoso 1996: 10). Moreover, in 1987, 27\% of Portuguese women were still working in agriculture - a rate surpassed only by Greece (35\%) against a European average of 7.3\%, and 50\% of women were working in the services sector against a European average of 70\% for the same period (Ferreira 1993: 241). ${ }^{12}$ Thus, in Portugal, “women's

11 In 2011 Portugal signed up to a structural adjustment programme with the IMF. The austeritydebt regime imposed since then has been particularly shaped by policies of labour devaluation.

12 In 2011 , the agricultural sector still employed $8.6 \%$ of Portuguese women (against, for instance, $2.4 \%$ in Spain and $0.7 \%$ in the UK); see Eurostat (2011:3). 
integration into the labour market has served the needs of the service economy, while perpetuating a traditional pattern of work distribution between the sexes" (Cardoso 1996: 18).

This incursion into the recent historical conditions shaping Portuguese women's entrance into the formal economy shows that the rapid and extensive entrance of Portuguese women into the formal economy is the result of contingent historical and economic processes, alongside emerging global trends of flexible patterns of labour mobilization and capital accumulation. The particularities of the Portuguese context reveal how certain historical features partly laid the groundwork for the contemporary profitable coexistence of devalued femininity and valued masculinity in the contemporary call centre customer service, described in the previous sections. Despite significant advances in women's condition in several spheres of social life and the pioneering legal codification of formal equality among women and men, an underdeveloped welfare state and the structural vulnerabilities of the Portuguese economic system (sustained by systematic practices of labour devaluation) prevent the practical realization of such equality, while contributing to the asymmetrical valuation of femininity and masculinity - as expressed in the call centre regime of labour. In the next section, I further argue that, within the context of intensified precarious employment conditions and unfulfilled projects of social mobility, male call centre operators are able to mobilize and display masculinity as a form of cultural capital structuring their own projects of self-valuation and status. This gender capital is expressed on the call centre shop floor particularly through a set of practices and discourses which configure a form of ritualized sexism, and outside the workplace as an asset conferring power and status to its owners.

\section{PRECARITY, CALL CENTRES AND MASCULINITY AS CULTURAL CAPITAL}

Aboim's (2010) recent research among three different generations of Portuguese men ${ }^{13}$ reveals that despite observed generational discontinuities, "the ultimate ideological barrier between men and women has not been broken down. Ideals related to motherhood, and to a lesser extent sexuality, still promote the difference between two gender "natures" (Aboim 2010: 158). The perpetuation of these two gender "natures" implies the persistence of unequal power relations between the sexes, as well as a material and discursive idiom of male domination (expressed, for instance, in men still having more access to public power and women still carrying the burden of domestic work and

13 The grandfathers (who lived under the authoritarian regime of Estado Novo), the fathers (who grew into adulthood during the post-revolutionary process of 1974) and the grandsons/sons (born and raised during the period of Portugal's membership of the EU). 
childcare responsibilities). The two gender "natures" to which Aboim alludes are informally and formally mobilized by management in the contemporary call centre sector, as I showed earlier in this article. The cultural idiom of female inferiority and masculine superiority is reproduced through the call centre labour process, by delivering to clients gendered products of labour congruent with the dominant national gender order. The commodification of a gender hierarchy does not in itself explain male call centre operators' complicity in the enactment/performance of gender differentiation in their daily work. My hypothesis is that, to understand the male shop floor culture I encountered - further detailed below - we need to look at the intersection of three different aspects: gender, neoliberal employment restructurings and class transformations; and these aspects must be seen as embedded in a particular economic and historical national tradition. I shall try to briefly detail this intersection grounded in the Portuguese context.

The generation of Portuguese female and male workers that has entered the call centre sector in the last decade faces an opposition between the employment conditions they have been able to achieve and the social expectations which were raised for them by their working-class parents and the state. The great majority of my interviewees were originally from Lisbon and born after the April 1974 revolution. After the revolution, the introduction of democratic principles was accompanied by growing hopes of upward social mobility through, for instance, educational achievement. More than half the workers interviewed are either studying at the university or have already completed their degrees. The majority of the parents of the persons interviewed migrated to Lisbon, particularly during the 1970s, looking for better jobs and living conditions for them and their children. Their sons and daughters were exposed to the "middle-class effect" (Estanque 2003) promoted by specific state policies, such as the provision of greater access to higher education to all social classes. The specific and late incorporation of stable and full employment in Portugal only fully benefited perhaps one generation - my interviewees' parents - having been progressively dismantled, especially after Portugal joined the EU. ${ }^{14}$ Nonetheless, the generation currently working in call centres internalized throughout the course of their lives the social hopes instilled by their parents, who associated stable employment and educational achievement with expectations of upward social mobility towards middle-class distinction.

In the last decade the successful growth of the call centre sector resulted, in part, from the availability and incorporation of a highly qualified surplus labour supply, constituted by a great number of young men and women in

14 A tendency towards the possibility of full employment was already apparent from the late 1960s under the corporatist regime, among certain economic sectors and in specific geographical areas, but which only expanded after the Carnation Revolution in 1974. 
possession of (devalued) higher education degrees but lacking in various forms of capital (e.g. social, economic), unable to manipulate social networks or invest in further training, with the goal of accessing permanent jobs. To a great extent, both male and female call centre operators could perhaps be characterized as a "failed middle-class" - whose humiliation has been publicly sanctioned, particularly by the media, with labels such as the "precarious 500 euros generation", trapped in low-wage and precarious work. Both female and male workers manifest social anxieties - expressed in feelings of dispossession, shame and stigma - resulting from unfulfilled projects of social mobility and middle-class status (Matos 2012). Nonetheless, owing to contingent historical and economic factors specific to the Portuguese context (described in the previous section) that have affected the fulfilment of gender equality in labour and employment, as well as specificities of the call centre labour process tending to reinforce the asymmetrical valuation of femininity and masculinity, male operators are able to deploy valued (hegemonic) masculinity as a form of capital. Among male operators, the instrumentalization of gender as a resource of self-valuation arises due to two interconnected factors, both linked to their labouring experience in the call centre sector. The performance of valued/hegemonic masculinity has the purpose of mitigating the potential emasculating effects of ( 1 ) inclusion in a devalued/feminized service sector - where workers are usually ascribed feminized characteristics, such as subservient and docile, assigned to routinized tasks, etc., and (2) middle-class precariousness. That is, what I found among the male call centre operators whom I followed more closely - in contrast to other contexts where social scientists have noted a "crisis of masculinity" (Newman 1988: 139; Mills 2003: 54; Ong 2006) was that the intensification of precarious employment conditions is leading to the valorization and deployment of hegemonic masculinity as a form of cultural capital. This is manifest in the way male workers display and mobilize masculinity as a resource of self-valuation (within the workplace) and social mobility (outside the workplace), with the goal of contradicting the metaphorical threat of demasculinization associated with integration in an undervalued (feminized) labour sector and unrealized projects of social mobility.

At EVA, the male workforce compliance with management's goals of female subordination and masculine authority commodification is manifest through a shop floor culture of assertive masculinity shaped by the enactment of ritualized sexism. Male call centre operators regularly plan physical activities to be carried out outside the workplace - car tuning, street racing, "LAN-parties", football matches and working out in the gym. ${ }^{15}$ The planning of these activities within the workplace affords male operators the opportunity to

15 A "LAN-party" is a gathering of persons with computers connected to each other in order to establish a "local area network" (LAN) in which computer games are played. 
distinguish themselves (from their female colleagues) as workers who assert their embodied masculinity as a value, which enables them to be in control of their bodies and emotions, in contrast to the stereotype of the "naturally sensitive woman". On the shop floor, male operators' assertion of the value of practice over theory (Willis 1977) further enhances assertive masculinity. Male operators often show an obsessive enthusiasm for the latest technological equipment (routers, mobile phones, web software, etc.). Colleagues usually refer to each other as "technological geeks" who are more interested in touching the equipment and learning its internal workings than in speculating which is best based on the advertised characteristics. By mastering the latest technological novelties male call centre workers encourage the belief among new and old colleagues that their tasks involve a certain "mastery" which the commercial helplines (composed of women) do not have. The group of male operators that I followed more closely used the equation "masculinity $=$ technology" as a way of exercising power over their female colleagues on the commercial helplines. By exercising power I mean presenting themselves as more dynamic, rational and proactive than their female colleagues on the commercial helplines, whom they subordinate as "inauthentic workers" (Cockburn 1985: 185). "Technological mastery" is not only claimed on the basis "that men have a natural leaning to technology" but also as a form of achieving recognition among peers for work performance. Thus, the masculinized appropriation of high-tech objects within call centres resembles cultural capital in its objectified state (Bourdieu 1986: 50), insofar as these objects are symbolically invested by agents with properties which sustain a gendered and unequal distinction among the workforce.

The practice of ritualized sexism is widely disseminated in the shop floor and usually expressed through jokes, aggressive macho humour, badinage and chauvinism. Sexist jokes often involve the objectification of women. One example - among several - of this kind took place in one of the cigarette breaks. The topic under discussion was the "woman with the perfect body". The conversation began with remarks about several parts of the bodies of their female colleagues on the commercial helplines, after which the conversation reached a consensus when one of the male operators suggested that the perfect woman would be "made" by "cutting one piece from each of them and then putting them together". Sexist jokes, either sent out by email or said in person, abounded among male operators, and they all tended to ritualize sexism as a form of asserting the superior value of masculinity. The extreme sexism (verging on misogyny) contained in the above story is not in itself new to anthropological research. In call centres, the praising and enactment of the "values of virility" (Bourdieu 2010 [1979]: 383-385) among male workers allows for the same kind of institutional recognition afforded by academic qualifications. That is, the institutionalized gender regime of the call centre 
labour process (embedded in the Portuguese dominant gender order described earlier) operates a hierarchical gendered distinction which allows the recognition of masculinity as a:

"conventional, constant, legally guaranteed value with respect to culture, [a] social alchemy [that] produces a form of cultural capital which has a relative autonomy vis-à-vis its bearer and even vis-à-vis the cultural capital he effectively possesses at a given moment in time" (Bourdieu 1986: 50-51).

Furthermore, male operators' adherence to the practices and discourses which constitute ritualized sexism actively reinforces management goals of embedding gender in the commodified products of labour. The commodification of a gender regime lends itself usefully to the goals of providing the client with the expected service, that is, with the expected male or female voice.

Outside the workplace, the mobilization of masculinity as a form of cultural capital by male call centre operators is first put into effect with a view to disguising their precarious workplace status within the private realm of the family, but also as an asset in the pursuit of individual projects of social mobility, with the purpose of pushing the boundaries of class status. When comparing themselves with their parents and in daily interactions with the nuclear family, male call centre operators mobilized their technical expertise as a way of stressing that they were partly successful in their projects of social mobility and class status. Unlike their working-class parents or their female colleagues in the commercial lines, they have technical expertise. ${ }^{16}$ Male call centre operators recurrently remarked that their parents' sense of frustration at finding their sons within a job that did not fit their qualifications was a matter of disguised shame and frustration. To counteract these feelings male call centre operators self-designate themselves as (male) "technicians", not (female) call centre operators. This means that, while they may experience conditions of employment insecurity, they are investing in fulfilling their own and their parents' dreams of social mobility by gaining work experience and improving the deployment of technical skills. Male call centre operators self-identification as "technicians" is reinforced by the fact that their call centre experience of technical provision facilitates access to masculine social networks related to programme software companies, as well as other companies in the informatics sector. Indeed, during fieldwork one male technical operator was able to move to a programme software company through contacts given to him by the team coordinator. Other male operators strategically invest in particular relationships with hierarchical superiors with a view to manipulating these 
good relations in the future for their own benefit - that is, of being able to access, through male friendship networks, jobs with higher status and prestige, according to public opinion, than those in the call centre sector. ${ }^{17}$

Thus, I am arguing that male call centre workers mobilize and enact masculinity as a form of cultural capital (Bourdieu 1986), which allows them to redefine/enhance their workplace and class status vis-a-vis their female colleagues and their working-class parents. ${ }^{18}$ Following Bourdieu (2001 [1998]), what I am arguing is that my male informants perceive and act on their own condition through "gendered habituses" (or gendered dispositions), and in doing so they both reproduce (unequal/hierarchical power relations between the sexes) and transform social reality (in a contingent manner, by disguising their workplace and class status). This argument draws inspiration from Freeman's (2000) research, which showed how femininity can be deployed as a form of cultural or symbolic capital with the purpose of pushing the boundaries of workplace and class status. The author's research in the offshore informatics industry in Barbados reveals how women workers actively contribute to the redefinition of their occupational and class status by converging with corporate interests in creating a "professional look" through the use of fashion and dress. There are striking contrasts and similarities between Freeman's research context and mine. Whereas in Barbados or in India the informatics sector is seen as containing the "promise of modernity", in Portugal the call centre sector has been demonized as the main locus of middle-class precariousness. Despite this contrasting context, the most important similarity is the convergence between management's goals of profitability or "professionalism" and the form(s) through which gender enables individuals - with a form of capital - to be simultaneously complicit in management goals and to dispute socially imposed identification(s) either with blue-collar workers (in Freeman's research) or with precarious, unprestigious and feminized work (in my research).

17 Earlier - see footnote 9 - I mentioned a study conducted in the mid 1990s on the significance of educational credentials in Portuguese women's trajectories of intergenerational social mobility (Mendes 1997). In a later publication, the same author concludes that educational credentials have progressively lost their structuring effect on women's trajectories of upward mobility and in narrowing gender-based differences in social mobility (Mendes 2006). In contrast, men's patterns of intergenerational social mobility remain the same in the two studies conducted. In particular, unlike working-class women, working-class men develop "upward trajectories inside their workplaces due to seniority, to work skills and to social networks", which constitute "an important means of social mobility that depends on male workers' personal and social capital” (Mendes 2006: 14-15).

18 Bourdieu, despite having written that "sexual properties are as inseparable from class properties as the yellowness of a lemon is from its acidity" (2010 [1979]: 102) never fully developed gender as a form of cultural capital. Such development has been recently proposed by feminists such as Skeggs (2004). 


\section{CONCLUSIONS}

I began this article by addressing how call centre firms capitalize on gendered hierarchies in order to best deliver to the client the "expected service". This was described as being in the first place inscribed on the workers' bodies, given that the central work carried out by operators is with their voices. Firms operate in accord with gender stereotypes which define female voices as sweet and docile and male voices as assertive and competent - a distinction that is reproduced in the division between commercial and technical helplines. Moreover, I have shown that the specific organization of value extraction at EVA's call centres presupposes an unequal gendered valuation of skills. Management deploys several formal and informal mechanisms for controlling and disciplining the enactment of gendered skills with the final aim of fulfilling customer expectations of docile femininity and masculine authority. It is with this aim in view that EVA's rhetoric of "the sovereign client" is put into effect, facilitating consent from workers and disguising the company's strategy of market segmentation. The unitary and indivisible figure of "the client" that is disseminated at EVA conceals the company's profitable dual strategy of undervalued feminized massification and valued masculinized customization of customer care.

The commodification of feminine subordination and masculine authority at EVA is mediated by specific economic and cultural trends pertaining to the recent history of Portugal, which have greatly conditioned and shaped gender-based inequalities in labour and employment. At the core of this national contingency are the specific conditions under which women have accessed formal employment and civil rights, following almost 40 years of a patriarchal dictatorship. Analysis of these conditions reveals the unfinished process of gender equality which began with the Carnation Revolution in 1974, due to the structural vulnerabilities attached to an underdeveloped welfare state and an economy based on low wages. My aim was not to argue that the recent history of the country determines the gender hierarchy activated at EVA's call centres, but that it works as a frame of legitimation for the practices and discourses engendering the mobilization and deployment of labour. The available literature on gender and call centre labour has concentrated excessively on analysing the feminization of this particular kind of work and its consequences for women, while neglecting analysis of how the relational and hierarchical aspects of gender, informed by specificities pertaining to context, can be subjected to commodification under communicative capitalism.

My argument that the valorisation process in the call centre regime of labour is dependent on the mobilization and deployment of a gender order particular to the Portuguese context is, ultimately, an aspect long emphasized by critical feminist theory. Capital accumulation is not only accumulated labour, it is also "an accumulation of differences and divisions within the working class, 
whereby hierarchies built upon gender, as well as 'race' and age, become constitutive of class rule and the formation of the modern proletariat" (Federeci 2004: 63-64). The historical development of the "free" wage labourer - the Marxist productive labourer - was only possible due to the (previous) superexploitation of women, slaves and colonies - the Marxist unproductive labourer (Mies 1986: 48). Several authors have vividly explored how gendered ideologies contribute to capital accumulation, focusing particularly on the functions of reproductive labour within the capitalist system as a form of reducing the value of labour power (Costa and James 1975; Fortunati 1995; Redclift 1988). Such authors have criticized the Marxist notion of productive labour for not treating the tasks involved in the reproduction of labour power - such as caring, feeding or nurturing people - as productive work. As partly stated by Hochschild (1983), when these tasks were transposed to the market, they remained subordinate to men's work. The call centre regime of labour, besides presenting an advanced apparatus for the exploitation of inherently human communicative abilities, also allows for the reproduction of women's subordination, showing clear continuities with labour regimes in the past. Moreover, following Graeber's (2001: 86) invocation of the Marxist labour theory of value, the differential value ascribed to femininity and masculinity in call centre labour results from its embeddedness in a "totality" - the dominant gender order - which is not reducible to the workplace. Social agents - both female and male - draw on this totality for the resources with which they can pursue their own individual projects of value - that is, their individual projects of social mobility. But, in order to realize their value, agents need, as Graeber points out, a point of comparison, an "imagined audience" (2001: 87). In the Portuguese call centre sector such an audience - that is, the call centre gender regime congruent with a dominant gender order - acts as an unequal system of value which both enables (men) and constrains (women), thereby conferring power on one part of the workforce while restricting the freedom of another.

To bring out how the call centre sector shapes, and is in turn shaped by, unequal gendered dispositions of entitlement and confidence, I have focused on the interplay of gender, precarity and projects of social mobility among the male operators whom I followed more closely. I have shown that the intensification of the neoliberal regulation of wage employment may not necessarily lead to a "crisis of masculinity". On the contrary, specific labour regimes informed by contingent historical and cultural factors may facilitate the strengthening of hegemonic masculinity. I have argued that this is the case in the Portuguese call centre sector, where male operators strategically deploy valued masculinity as a way of counteracting their integration into feminized labour and feelings of middle-class precariousness. This analysis has, I believe, broader implications, particularly with regard to the invisibility of gender in the proposals put forward by autonomist Marxists on immateriality and precarity. That is, 
I have shown that neither immateriality nor precarity are gender-neutral realms. Rather, particular national historical (latent or manifest) ideologies of gender inequality interact with immaterial regimes of value production in ways that affect individual projects of self-valuation and social mobility among those labelled as the precariat. In the Portuguese call centre sector, male domination prevails over a devalued and feminized labour regime. That is, femininity and masculinity within the call centre sector are not "two sides of the same coin". The asymmetrical value of femininity and masculinity results from the mutual reproduction of two kinds of accumulation strategies corresponding to two different forms of capital, both built upon contextually national specificities and global neoliberalization processes (precarity). This asymmetrical valuation is institutionalized in the labour process through a gendered redefinition of skills grounded on a cultural grammar of the inferior status of women and femininity, and masculine superiority; and another which derives from male call centre operators' investment strategies in assertive masculinity as a form of cultural capital, allowing them to negotiate their status in the workplace and within society at large.

\section{REFERENCES}

ABOIM, Sofia, 2010, Plural Masculinities. Aldershot, Ashgate.

ALMEIDA, Miguel Vale de, 1996, The Hegemonic Male. Oxford, Berghahn Books.

BASI, J. K. Tina, 2009, Women, Identity and India's Call-Centre Industry. London, Routledge.

BEAR, Laura, 2007, "Re-working the national in global capitalism: freedom and consumption in the lives of international call centre workers in Kolkata", paper presented at "Rethinking Economies - Moral Economies in Practice", King's College/University of Cambridge, $28^{\text {th }}$ April.

BELT, Vicki, 2002, "A female ghetto? Women's careers in call centres", Human Resource Management Journal, 12 (4): 51-66.

BOURDIEU, Pierre, 1986, "The forms of capital", in A.H. Halsey et al. (eds.), Education:

Culture, Economy, and Society. Oxford, Oxford University Press, 46-58.

BOURDIEU, Pierre, 2001 [1998], Masculine Domination. Stanford, Stanford University Press. BOURDIEU, Pierre, 2010 [1979], Distinction. London, Routledge.

BRAVERMAN, Harry, 1974, Labor and Monopoly Capital. New York, Monthly Review Press. CAMERON, Deborah, 2000, "Styling the worker: gender and the commodification of language in the globalized service economy", Journal of Sociolinguistics, 4 (3): 323-347.

CARDOSO, Ana Rute, 1996, "Women at work and economic development: who's pushing what?", Review of Radical Political Economics, 28 (3): 1-34. 
CASACA, Sara Falcão, 2010, "A (des)igualdade de género e a precarização do emprego", in Virgínia Ferreira (ed.), A Igualdade de Mulheres e Homens no Trabalho e no Emprego em Portugal. Lisboa, Comissão para a Igualdade no Trabalho e no Emprego/Ministério do Trabalho e da Solidariedade Social, 261-291.

CASACA, Sara Falcão, 2012, Trabalho Emocional e Trabalho Estético. Coimbra, Almedina.

COCKBURN, Cynthia, 1985, Machinery of Dominance. London, Pluto Press.

CONnell, R.W., 1987, Gender and Power. Cambridge, Polity Press.

COSTA, Mariarosa Dalla, and Selma JAMES, 1975, The Power of Women and the Subversion of the Community. London, Falling Wall Press.

ELSON, Diane, and Ruth PEARSON, 1981, “Nimble fingers make cheap workers': an analysis of women's employment in Third World export manufacturing", Feminist Review, 7: 87-107.

ESTANQUE, Elísio, 2003, “O 'efeito classe média': desigualdades e oportunidades no limiar do século XXI”, in Manuel Villaverde Cabral, Jorge Vala, and André Freire (eds.), Desigualdades Sociais e Percepções de Justiça. Lisboa, Imprensa de Ciências Sociais, 69-105.

EUROSTAT, 201 1, "European Union Labour Force Survey-Annual results 201 1", available at <http://epp.eurostat.ec.europa.eu/cache/ITY_OFFPUB/KS-SF-12-040/EN/KS-SF-12-040 -EN.PDF $>$ (last access 2014, February).

EUROSTAT, 2013, European Social Statistics - 2013 Edition. Luxembourg, Publications Office of the European Union, available at <http://epp.eurostat.ec.europa.eu/cache/ITY OFFPUB/KS-FP-13-001/EN/KS-FP-13-001-EN.PDF > (last access 2014, February).

FEDERECI, Silvia, 2004, Caliban and the Witch. Brooklyn, NY, Autonomedia.

FEDERECI, Silvia, 2008, "Precarious labor: a feminist viewpoint", The Journal of Aesthetics and Protest, available at <http://inthemiddleofthewhirlwind.wordpress.com/precariouslabor-a-feminist-viewpoint/> (last access 2014, February).

FERREIRA, Virgínia, 1993, "Padrões de segregação das mulheres no emprego: uma análise do caso português no quadro europeu", in Boaventura de Sousa Santos (ed.), Portugal: Um Retrato Singular. Porto, Afrontamento, 233-257.

FERREIRA, Virgínia 1999, “Os paradoxos da situação das mulheres em Portugal”, Revista Crítica de Ciências Sociais, 52-53: 199-227.

FORTUNATI, Leopoldina, 1995, The Arcane of Reproduction. Brooklyn, NY, Autonomedia.

FOTI, Alex, 2004, "Precarity and n/European identity: an interview with Alex Foti (Chainworkers)", Mute, 2 (0), October, available at <http://www.metamute.org/edito$\mathrm{rial} /$ articles/precarity-and-neuropean-identity-interview-alex-foti-chainworkers $>$ (last access 2014, February).

FRADE, Carlos, Isabelle DARMON, and Miguel LAPARRA, 2004, "Precarious employment in Europe: a comparative study of labour market related risk in flexible economies", Esope Project, European Commission, available at $<$ http://ec.europa.eu/research/social-sciences/pdf/finalreport/hpse-ct-2001-00075-final-report.pdf $>$ (last access 2014, February). FREEMAN, Carla, 2000, High Tech and High Heels in the Global Economy. Durham and London, Duke University Press.

GRAEBER, David, 2001, Toward an Anthropological Theory of Value. New York/Basingstoke, Palgrave.

HARDT, Michael, and Antonio NEGRI, 2000, Empire. Cambridge, MA, Harvard University Press.

HARDT, Michael, and Antonio NEGRI, 2005, Multitude. London, Penguin Books. 
HARVEY, David, 1989, The Condition of Postmodernity. Oxford, Basil Blackwell.

HOCHSCHILD, Arlie, 1983, The Managed Heart. Berkeley, University of California Press.

HOLMAN, David, R. Batt, and U. Holtgrewe, 2007, The Global Call Center Report: International Perspectives on Management and Employment, electronic version. Ithaca, NY, authors publishing, ILR Collection - Research Studies and Reports, available at <http://digitalcommons.ilr.cornell.edu/reports/13> (last access 2014, February).

HOLTGREWE, Ursula, et al., 2009, "Global or embedded service work? the (limited) transnationalisation of the call-centre industry", Work Organisation, Labour and Globalisation, 3 (1): 9-25.

LAZZARATO, Maurizio, 1996, "Immaterial labour", in Michael Hardt and Paolo Virno (eds.), Radical Thought in Italy. Minneapolis, University of Minnesota Press, 133-146.

MARX, Karl, 1990 [1867], Capital, vol. 1. London, Penguin Books.

MATOS, Patrícia, 2012, "Call center labor and the injured precariat: shame, stigma, and downward social mobility in contemporary Portugal”, Dialectical Anthropology, 36 (3): 217-243.

MENDES, José, 1997, "Mobilidade social em Portugal: o papel da diferença sexual e das qualificações”, Revista Crítica de Ciências Sociais, 49: 127-156.

MENDES, José, 2006, "Intergenerational mobility and social inequalities in a comparative perspective”, available at <http://www.ces.uc.pt/publicacoes/oficina/ficheiros/246.pdf> (last access 2014, February).

MIES, Maria, 1986, Patriarchy and Accumulation on a World Scale. London, Zed Books.

MILLS, Mary Beth, 2003, "Gender and inequality in the global labor force", Annual Review of Anthropology, 23: 41-62.

MITROPOULOS, Angela, 2006, "Precari-us?", Mute, 1 (29), January, available at <http://www.metamute.org/editorial/articles/precari-us> (last access 2014, February).

MUKHERJEE, Sanjukta, 2008, "Producing the knowledge professional: gendered geographies of alienation in India's new high-tech workplace", in Carol Upadhya and A.R. Vasavi (eds.), In an Outpost of the Global Information Economy: Work and Workers in India's Information Technology Industry. New Delhi, Routledge, 50-75.

NASH, June, and María Patricia FERNÁNDEZ-KELlY (eds.), 1983, Women, Men, and the International Division of Labor. New York, State University of New York Press.

NEWMAN, Katherine S., 1988, Falling from Grace. Berkeley and Los Angeles, University of California Press.

NG, Cecilia, and Swasti MITTER, 2005a, "Valuing women's voices: call center workers in Malaysia and India”, in Cecilia Ng and Swasti Mitter (eds.), Gender and the Digital Economy. London, Sage, 132-158.

NG, Cecilia, and Swasti MITTER (eds.), 2005b, Gender and the Digital Economy. London, Sage.

ONG, Aihwa, 1987, Spirits of Resistance and Capitalist Discipline. New York, State University of New York Press.

ONG, Aihwa, 2006, "Labour arbitrage: displacements and betrayals in Silicon Valley", in Aihwa Ong, Neoliberalism as Exception. Durham and London, Duke University Press, 157-174.

PATEL, Reena, 2010, Working the Night Shift. Stanford, CA, Stanford University Press.

PERISTA, Heloísa, 2002, "Género e trabalho não pago: os tempos das mulheres e os tempos dos homens", Análise Social, XXXVII (163), 447-74. 
PINA-CABRAL, João de, 1986, Sons of Adam, Daughters of Eve. Oxford, Claredon Press.

REDCLIFT, Nanneke, 1988, "Gender, accumulation and the labour process", in R.E. Pahl

(ed.), On Work. Oxford, Basil Blackwell, 428-448.

ROSAS, Fernando, 1998, O Estado Novo (1926-1974). Lisboa, Editorial Estampa.

ROSS, Andrew, 2008, "The new geography of work: power to the precarious?", Theory, Culture \& Society, 25 (7-8): 31-49.

ROSS, Andrew, 2009, Nice Work If You Can Get It. New York, New York University Press.

SALZINGER, Leslie, 2003, Genders in Production. Berkeley, University of California Press.

SANTOS, Boaventura de Sousa, et al., 1990, "O Estado e as transformações recentes da relação salarial”, in Boaventura de Sousa Santos (ed.), O Estado e a Sociedade em Portugal (1974-1988). Porto, Afrontamento, 151-191.

SASSEN, Saskia, 1998, Globalization and its Discontents. New York, New Press.

SILVA, Manuela, 1983, O Emprego das Mulheres em Portugal. Porto, Afrontamento.

SKEGGS, Beverley, 2004, "Context and background: Pierre Bourdieu's analysis of class, gender and sexuality”, in Lisa Adkins and Beverley Skeggs (eds.), Feminism after Bourdieu . London, Blackwell, 19-33.

STANDING, Guy, 2011 , The Precariat. London, Bloomsbury.

TORRES, Anália, 2009, "Women, gender, and work: the Portuguese case in the context of the European Union”, International Journal of Sociology, 38 (4): 35-56.

UPADHYA, Carol, 2006, "Gender issues in the Indian software outsourcing industry", in Anita Gurumurthy et al. (eds.), Gender in the Information Society. India, Asia-Pacific Development Information Programme (APDIP), 74-84.

UPADHYA, Carol, and A. R. VASAVI, 2006, Work, Culture, and Sociality in the Indian IT Industry: A Sociological Study, final report submitted to Indo-Dutch Programme for Alternatives in Development, available at < http://www.uni-kassel.de/ tduermei/iksa/readerengl/addtext\%2013Updadhya\%202006\%20Work,\%20Culture\%20and\%20Sociality-1.pdf> (last access 2014, February).

WACQUANT, Loïc, 2008, Urban Outcasts. Cambridge, Polity Press.

WILLIS, Paul, 1977, Learning to Labour. London, Gower Publishing Group.

WRIGHT, Melissa W., 2006, Disposable Women and Other Myths of Global Capitalism. London, Routledge. 